\title{
Morphology and typification of Szovitsia callicarpa (Apiaceae)
}

\author{
Mustafa ÇELIK ${ }^{*}$, Özal GÜNER² ${ }^{2}$ Özlem ÇETIN ${ }^{3}$, Bilal ŞAHIN ${ }^{4}$, P. Pablo FERRER-GALLEGO ${ }^{5}$ \\ ${ }^{1}$ Advanced Technology Research and Application Center, Selçuk University, Konya, Turkey. \\ ${ }^{2}$ Department of Biology, Faculty of Science, Gazi University, Ankara, Turkey. \\ ${ }^{3}$ Department of Biotechnology, Faculty of Science, Selçuk University, Konya, Turkey. \\ ${ }^{4}$ Yapraklı Vocational School, Çankırı Karatekin University, Çankırı, Turkey. \\ ${ }^{5}$ Servicio de Vida Silvestre, Centro para la Investigación y Experimentación Forestal (CIEF), \\ Generalitat Valenciana, Avda. Comarques del País Valencià 114, 46930 Quart de Poblet, Valencia, Spain. \\ *Correspondence: mstfclk.54@gmail.com \\ ${ }^{1}$ https://orcid.org/0000-0002-2708-9944, ${ }^{2}$ https://orcid.org/0000-0002-5998-8530 \\ ${ }^{3} \mathrm{https}: / /$ orcid.org/0000-0003-2886-3409, ${ }^{4} \mathrm{https}: / /$ orcid.org/0000-0003-1569-7771 \\ ${ }^{5}$ https://orcid.org/0000-0001-7595-9302
}

\begin{abstract}
The poorly known monotypic genus Szovitsia Fisch. \& C.A.Mey, in the Apiaceae family, is here revised. Szovitsia callicarpa Fisch. \& C.A.Mey. is an annual herb with a restricted distribution in the Caucasus region and adjacent areas of northwestern Iran and northeastern Turkey. The genus is unusual within the family because of the transverse plicae covering its fruits. In this study, morphological, micromorphological, and anatomical characters of $S$. callicarpa are reviewed. In addition, a previous lectotypification of the name $S$. callicarpa is discussed and amended.
\end{abstract}

Keywords. Anatolia, anatomy, Caucasus, lectotype, monotypic genus, Szovitsia.
Resumen. Se revisa Szovitsia Fisch. \& C.A.Mey, un género monotípico y poco conocido en la familia de las Apiaceae. Szovitsia callicarpa Fisch. \& C.A.Mey. es una hierba anual con una distribución restringida a la región del Cáucaso y áreas adyacentes del noroeste de Irán y noreste de Turquía. El género es inusual dentro de la familia debido a los pliegues transversales que cubren sus frutos. En este estudio se revisan los caracteres morfológicos, micromorfológicos y anatómicos de esta especie. También se discute y modifica una lectotipificación previa del nombre $S$. callicarpa.

Palabras clave. Anatolia, anatomía, Cáucaso, género monotípico, lectótipo, Szovitsia.

How to cite this article: Çelik M., Güner Ö., Çetin Ö., Şahin B. \& Ferrer-Gallego P.P. 2020. Morphology and typification of Szovitsia callicarpa (Apiaceae). Anales del Jardín Botánico de Madrid 77: e101. https://doi.org/10.3989/ajbm.2521

Title in Spanish: Morfología y tipificación de Szovitsia callicarpa (Apiaceae).

Associate Editor: Carlos Aedo. Received: 14 February 2019; accepted: 23 October 2020; published online: 21 December 2020.

\section{INTRODUCTION}

Southwest Asia is an area of great interest because of its high plant diversity and endemism. The level of endemism is generally used to indicate the uniqueness of a flora and is a major criterion for conservation (Sales \& Hedge 2013). According to Sales \& Hedge (2013), there are 161 endemic genera in southwest Asia and $70 \%$ of these are monotypic. Most of these endemic species belong to the families Apiaceae, Asteraceae, and Brassicaceae (Sales \& Hedge 2013). Different researchers have documented Apiaceae richness in the area (Davis 1972; Rechinger 1987; Ekim 2009; Sales \& Hedge 2013), with 281 genera and 2115 species reported from Asia by Pimenov \& Leonov (2004a). The family Apiaceae has the highest number of genera endemic to Asia (60), of which 45 are monotypic (Sales \& Hedge 2013).

The distribution of species and generic diversity among Asian countries is extremely uneven. The countries with the greatest biodiversity of Apiaceae are China (672 spp.),
Turkey (Asian area, 453 spp.), Iran (362 spp.), Russia (Asian area, 276 spp.), Kazakhstan (234 spp.), and India (227 spp.). Asian Turkey (Anatolia), with its relatively small area, has the highest concentration of species of Apiaceae not only in Asia, but possibly in the entire world (Pimenov \& Leonov 2004b).

Szovitsia is a monotypic genus, and the species S. callicarpa is distributed in a very restricted area of the Caucasus region and surrounding areas, covering NW Iran, Armenia, Karabagh, Nakhichevan, and NE Anatolia. The only reports on the morphology of Szovitsia are those included in regional floras. Detailed morphological, anatomical, and palynological studies on the genus are practically nonexistent in the botanical literature. Therefore, the purpose of this study was to revise the genus and provide a detailed account of the morphological, palynological, anatomical, and micromorphological characteristics of S. callicarpa, and assess their taxonomic significance. The lectotypification of $S$. callicarpa is also discussed. 


\section{MATERIAL AND METHODS}

The two specimens used in the morphological analysis were collected in Turkey: Iğdır, northeast of Tuzluca, 1075 m, 19 May 2018, Ö. Güner 6643 (GAZI); 1-3 km from Tuzluca to Kağızman, 1100 m, 3 Jun. 2018, B. Şahin 7367 (GAZI). Plant samples were identified according to Peşmen (1972), Shishkin (1973) and Rechinger (1987).

For the micromorphological study, pollen slides were prepared according to Wodehouse (1935). Measurements, based on 20 samples, were taken with a Leica microscope. For Scanning Electron Microscope (SEM) investigations, fruit and pollen grains were mounted directly onto the prepared stubs and coated with gold, using a Polaron SC7620 sputter coater. Photographs of the specimens were taken using an incorporated Zeiss LS-10 camera, and the terminologies of Erdtman (1952) and Faegri \& Iversen (1975) were used for the micromorphological features.

Mericarps, for the anatomical study, were rehydrated and placed in formalin-acetic acid-alcohol (1:1:8) for at least $24 \mathrm{~h}$. Rehydrated materials were embedded into paraffin blocks following the traditional paraffin section method. Transverse sections were cut about $10 \mu \mathrm{m}$ thickness using a microtome and stained with safranin solution. Micrographs were taken using a Leica stereomicroscope.

\section{RESULTS}

\section{Typification and emended description}

Fischer \& Meyer (1835: 39) described Szovitsia callicarpa as follows: "Herba annua, glabra, foliis compositis v. decompositis, laciniis elongatis filiformibus, umbellis lateralibus, involucris nullis, involucellis 5-6-phyllis membranaceis, floribus albis". They also included the provenance of the species: "Hab. in desertis salsis prope Nakitschiwan, nec non in locis lapidosis provinciae Karabagh".

On the other hand, Peşmen (1972: 420) indicated: "Type: [Soviet Armenia] in desertis salsis prope Nakitschiwan?; nec non in locis provinciae Karabagh, Szovits (iso. K!)". Johann Nepomuk Szovits, after Ivan Osipovich Sovich, was a pharmacist who collected extensively during 1828-1830 in Armenia, Karabakh, Imeretia, Mingrelia, and Iranian Azerbaidzhan. In the herbarium of the Royal Botanic Gardens, Kew (K) there are three relevant herbarium sheets, K 000681162, K 000681163, and K 000681165. The sheet K 000681162 was collected by Fischer and it bears a complete plant with leaves and flowers. This sheet (K 000681162) has the label "Szovitsia callicarpa / E. prov: Karabagh et prope Nakitschi- / wan" and the annotation "D. Fischer". The sheet K 000681163 bears a complete plant, with leaves and fruits, and also a plant fragment. It is annotated as
"Szovitsia callicarpa / (bis) / D. Fischer" (K 000681163). Clearly, the specimen K 000681163 can be treated as a duplicate of the specimen K 000681162 . Finally, the third specimen (K 000681165) (Fig. 1) bears a plant with leaves and fruits, and also a plant fragment, and it has the label "408 / Ex herbario horti Petropolitani [printed] / Szovitsia callicarpa F. et M. / Karabagh / Szovits".

These three specimens (K 000681162, K 000681163 , and K 000681165 ) can be treated as original material of Szovitsia callicarpa. However, as Peşmen (1972: 420) mentioned the collector name, as "Szovits", the sheet indicated in the typification is clearly the specimen $\mathrm{K}$ 000681165 , and therefore it must be treated as the type of the name $S$. callicarpa, in this case as a lectotype. On the other hand, Shishkin (1973: 364) indicated: “Type in Leningrad", and Leute (1987: 158) mentioned "Typus: Karabagh, A.J. Szovits 408, W!". However, these two "typifications" are ineffective and superfluous. Furthermore, there are some specimens of $S$. callicarpa in several herbaria that can be treated as part of the original material, and concretely as duplicate specimens of the lectotype (e.g., C, G, K, L, LE, P, U, W).

Szovitsia Fisch. \& C.A. Mey., Index Sem. Hort. Petrop.1: 39. 1835 .

\section{Type: Szovitsia callicarpa Fisch. \& C.A. Mey.}

Szovitsia callicarpa Fisch. \& C.A. Mey., Ind. Sem. Hort. Petrop. 1: 39. 1835. Type: [Armenia] Nakitschiwan, Karabagh, Szovits 408 (lectotype designated by Peşmen 1972: 420 as "iso." [isotype], and corrected here according to ICN Art. 9.10: K 000681165; isotypes: C 10008569, G 00359601, L.2589242 (Herb. Lugd. Bat. No 908.2651240), LE 01043593, P 03214069, U 1090342, W-Rchb. 1889-0308677).

Annual herbs with slender roots, spreading-erect, branching from the base, rarely from the middle or upper part. Stem (15-)25-60 $\mathrm{cm}$, thin, up to $2.5 \mathrm{~mm}$ diameter, completely glabrous. Radical leaves soon withering; lamina triangular-ovate in outline, 2- to 3-pinnate, 3.5-6.5 × 3-5 cm; petiole shorter than rachis with small sheathing at the base; ultimate segments linear, 3-8 $\times$ ca. $0.5 \mathrm{~mm}$. Basal and middle cauline leaves broadly ovate in outline, $3.5-8 \mathrm{~cm}$. long (incl. petiole); ultimate segments linear-filiform, up to $35 \mathrm{~mm}$ long. Upper cauline leaves pinnatisect with filiform segments. Umbel compound, 3-8(-11) rayed, (1-)2-3.5 cm long, nearly equal, thin, glabrous. Bracts absent or rarely 1. Bracteoles 5-6, lanceolate, widely membranous margin, ciliate in the upper part, acuminate to subulate, 2-5 $\times$ 0.8-1.2 mm. Umbellula (3-)-5-11 flowered, pedicels unequal, 6-14 $\mathrm{mm}$ in fruit. Flowers hermaphrodite. Calyx teeth obsolete or minute, triangular. Petals white, obovate, inwardly curved ligule, up to $3 \mathrm{~mm}$, rough on the base of dorsal surface. Fruits oblong-elliptic, slightly laterally compressed, 3-6 × 2-3.5 mm. Mericarps 2, homomorphic, 


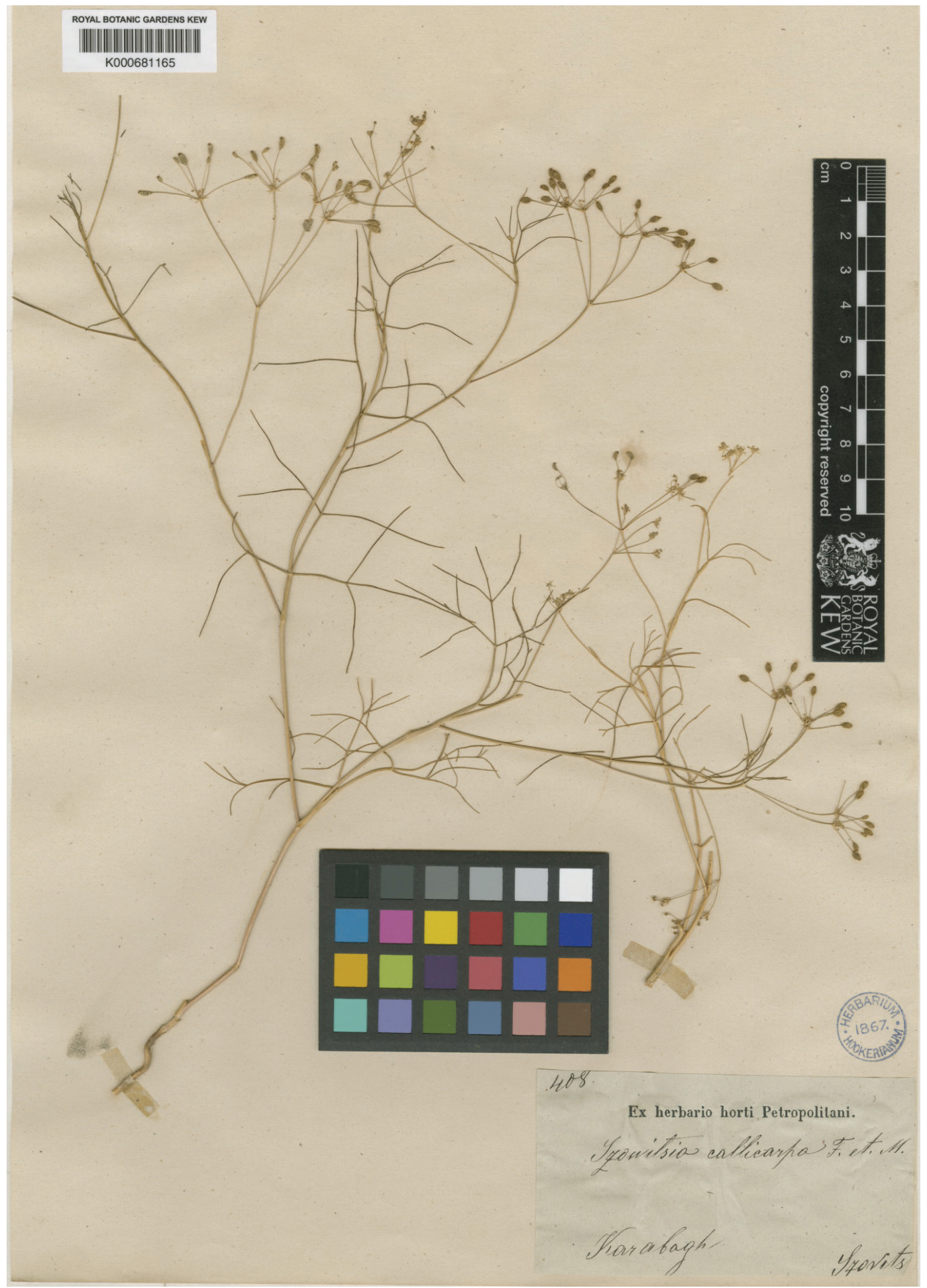

Fig. 1. Lectotype of Szovitsia callicarpa Fisch. \& C.A. Mey. (K 000681165). Image courtesy of the K herbarium.

elliptic with primary and secondary ribs; primary ribs filiform, secondary ribs covered by imbricate plicae, broadly elevated. Stylopodium depressed or short conical, styles spreading or recurved, ca. $1 \mathrm{~mm}$ long. Vallecular vitta 1 , commissural vittae 2 . Figs. $2-3$.
Flowering time.-May-June.

Choromosome number. $-n=10$ (Shner \& al. 2005).

Distribution.-Northwestern Iran, Armenia, Karabagh, Nakhichevan, and northeastern Anatolia (Turkey). 


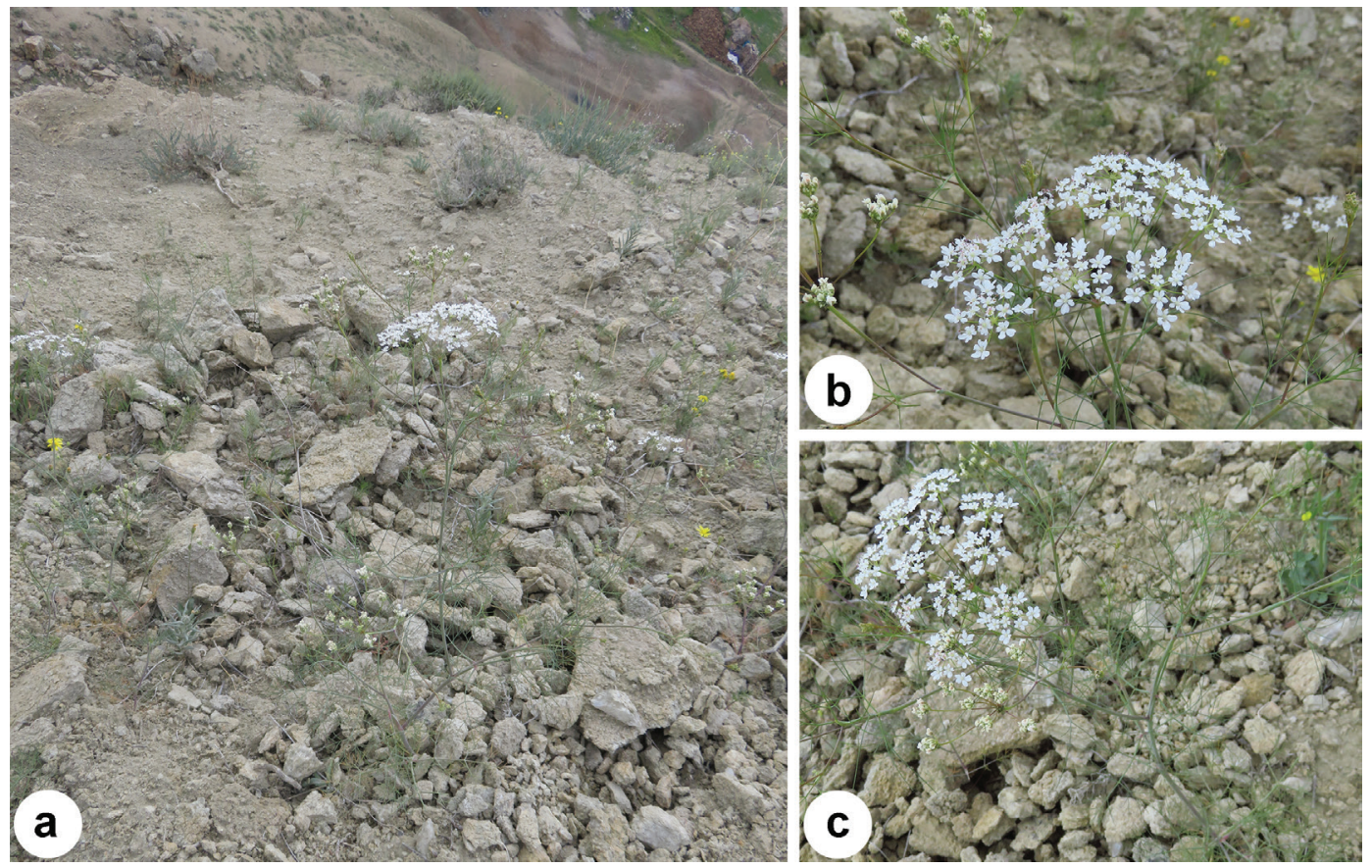

Fig. 2. Szovitsia callicarpa in its natural habitat: a, habit; b, detail of the umbel; c, fertile branch.

\section{Fruit anatomy and morphology}

In the transverse section, mericarps of Szovitsia callicarpa are nearly semi-circular. The fruits have five indistincly primary ribs. Secondary ribs are also present. The exocarp is a single-layered with the exocarp cells radially elongated or rarely square. The outer cell walls are slightly thickened and covered with a cuticle layer. The mesocarp consists of parenchymatous cells. Vittae are elliptic and relatively large. The number of the vallecular vittae is 1 , and the number of the commissural vittae is 2 . The vascular bundle is small and solitary in each primary rib. The endosperm, in transverse section, has an oval shape, slightly impressed on commissural side (Fig. 4).

In addition to the features included in the description above, the fruits of $S$. callicarpa have primary ribs that are barely discernible, because they are nearly completely covered by the edges of the secondary ribs. Moreover, the primary ribs and base of the fruit are setulose (Fig. 5a). There are four distinct, broad, and elevated secondary ribs that are covered by imbricate plicae that completely fill the furrows. The plicae are narrower at both the base and top (Fig. 5c), and they are concave and papillose (Fig. 5d). A beak-shaped structure has been observed in the middle part of plicae. The stylopodium is depressed or short and conical and is situated at a considerable height because it expands from the area in which the plica ends. The styles are $1 \mathrm{~mm}$ long and spreading or recurved (Fig. 5a). Calyx teeth are obsolete or minute and triangular (Fig. 5b).

\section{Palynology}

The pollen grains of Szovitsia callicarpa are monad, isopolar, radially symmetric and tricolporate. The polar axis $(\mathrm{P})$ ranges from 28.77 to $32.99 \mu \mathrm{m}$ and the equatorial axis (E) ranges from 13.02 to $15.08 \mu \mathrm{m}$. The exine thickness ranges from $0.71 \mu \mathrm{m}$ to $1.03 \mu \mathrm{m}$ and the intine thickness ranges from $0.43 \mu \mathrm{m}$ to $0.63 \mu \mathrm{m}$. The ratio of the length of the polar axis to the equatorial diameter $(\mathrm{P} / \mathrm{E})$ averaged $2.13 \pm 0.07$ making the pollen grain shape perprolate. In polar view, the pollen grains are nearly triangular with obtuse angles. In equatorial view, the grains are narrowly oblong, having a slightly equatorial constriction and obtuse polar caps. The colpus extends to the near poles. The pore area is slightly protruding and is located in the middle of the colpus. The sculpturing pattern is irregularly rugulate, sometimes psilate between the pole and the equatorial area (Fig. 6).

\section{DISCUSSION}

Turkey is one of the richest countries in the world in Apiaceae species. A recent account, indicated that the family is represented by 104 genera and 486 species, with three monotypic endemic genera to the country (Aegokeras Raf., Postiella Kljuykov, and Crenosciadium Boiss. \& Heldr. ex Boiss.). Of the 182 taxa endemic to Turkey, 45 belong to Apiaceae (Güner \& al. 2012).

Szovitsia callicarpa has a limited geographical extension and is distributed in NW Iran, Armenia, Karabagh, 

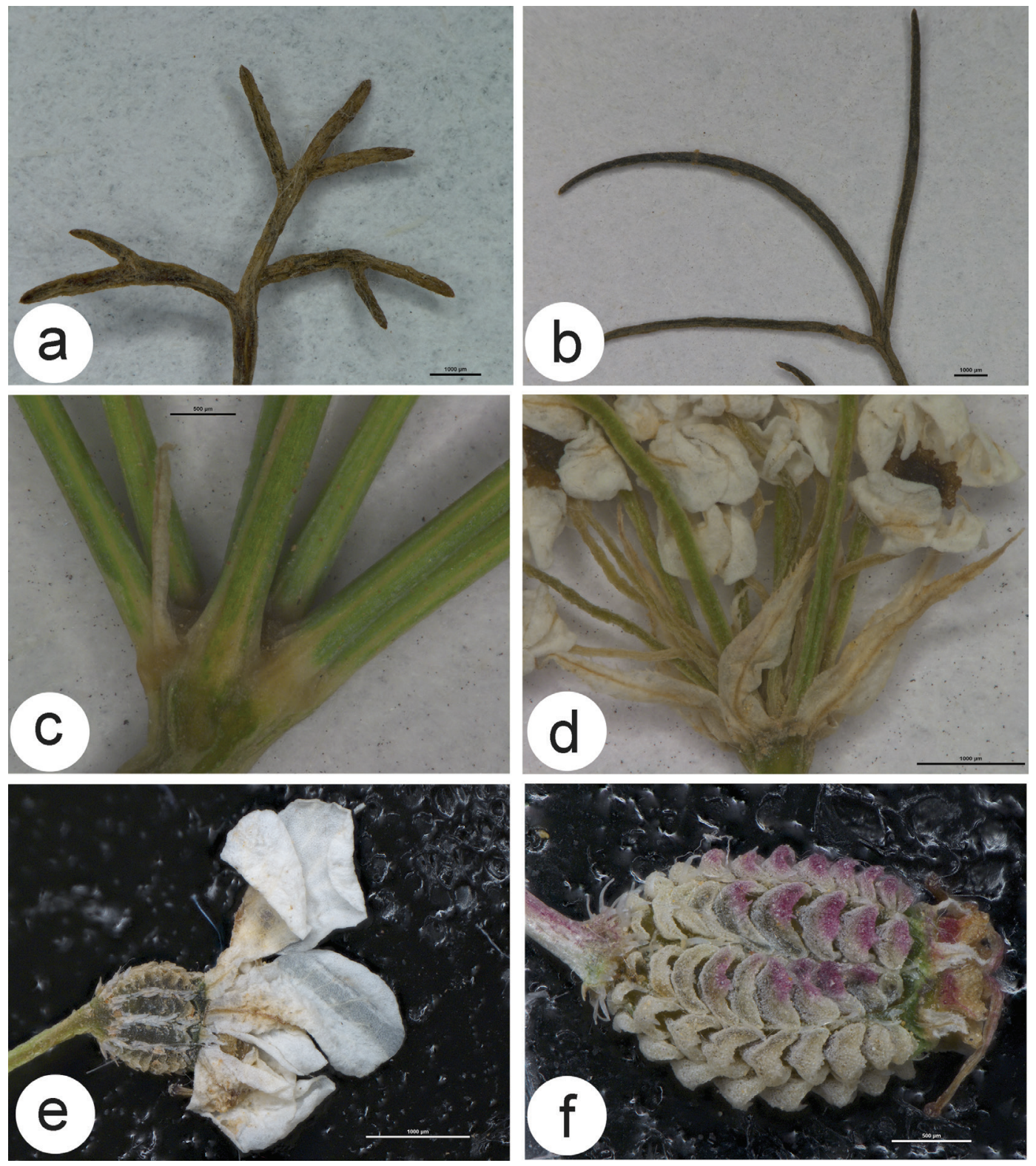

Fig. 3. Detail of leaf, flower, and fruit of Szovitsia callicarpa: a, basal leaf segments; $\mathbf{b}$, cauline leaf segments; $\mathbf{c}$, bract; d, bracteoles; $\mathbf{e}$, dorsal surface of petals; $\mathbf{f}$, general view of fruit and plicae.

Nakhichevan, and Turkey (NE Anatolia). The species is known only from the salty-gypseous soils in Iğdır and Kars in Turkey (Fig. 7) and has not been collected in the centralwestern part the country. The Iğdır-Yerevan basin was formed by stratification with alluvium materials carried by the Aras River and the precipitated sediments in stagnant water over cenozoic (Davis 1965). This sedimentary basin is composed of soils with high mineral and salt contents. The average annual rainfall is $250 \mathrm{~mm}$, and the average maximum temperature is $12^{\circ} \mathrm{C}$ in the basin. Most of the annual precipitation falls during spring and early summer, and severe drought begins after the rainy period. These climate and environmental characteristics determine the species' extremely short growing season. Pressure from overgrazing and erosion, has resulted in the reduction of the vegetation coverage on the slopes around the basin. The vegetation in this area is dominated by Atraphaxis spinosa L., a shrub resistant to the severe environmental conditions. Ephemeral plants that must complete their life cycles before the high summer temperatures and grazing pressure, grow under this spiny shrub on the slopes. Szovitsia callicarpa is one of these plants. It grows in semi-arid deserts and steppe slopes that are characterized by eroded, overgrazed, andsaline soils. Other species co- 


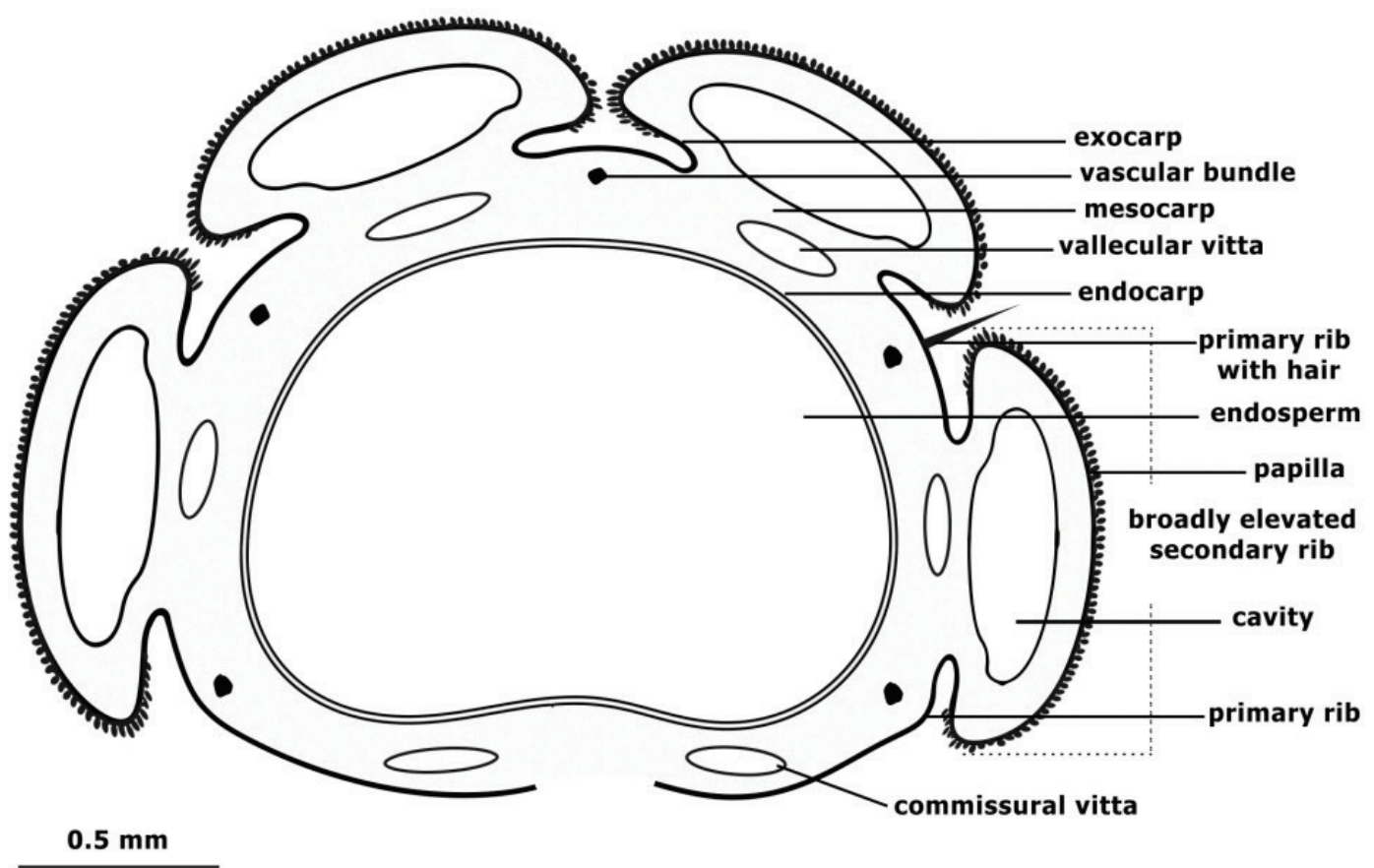

Fig. 4. Schematic structure of the fruit cross-section of Szovitsia callicarpa, indicating the main features.
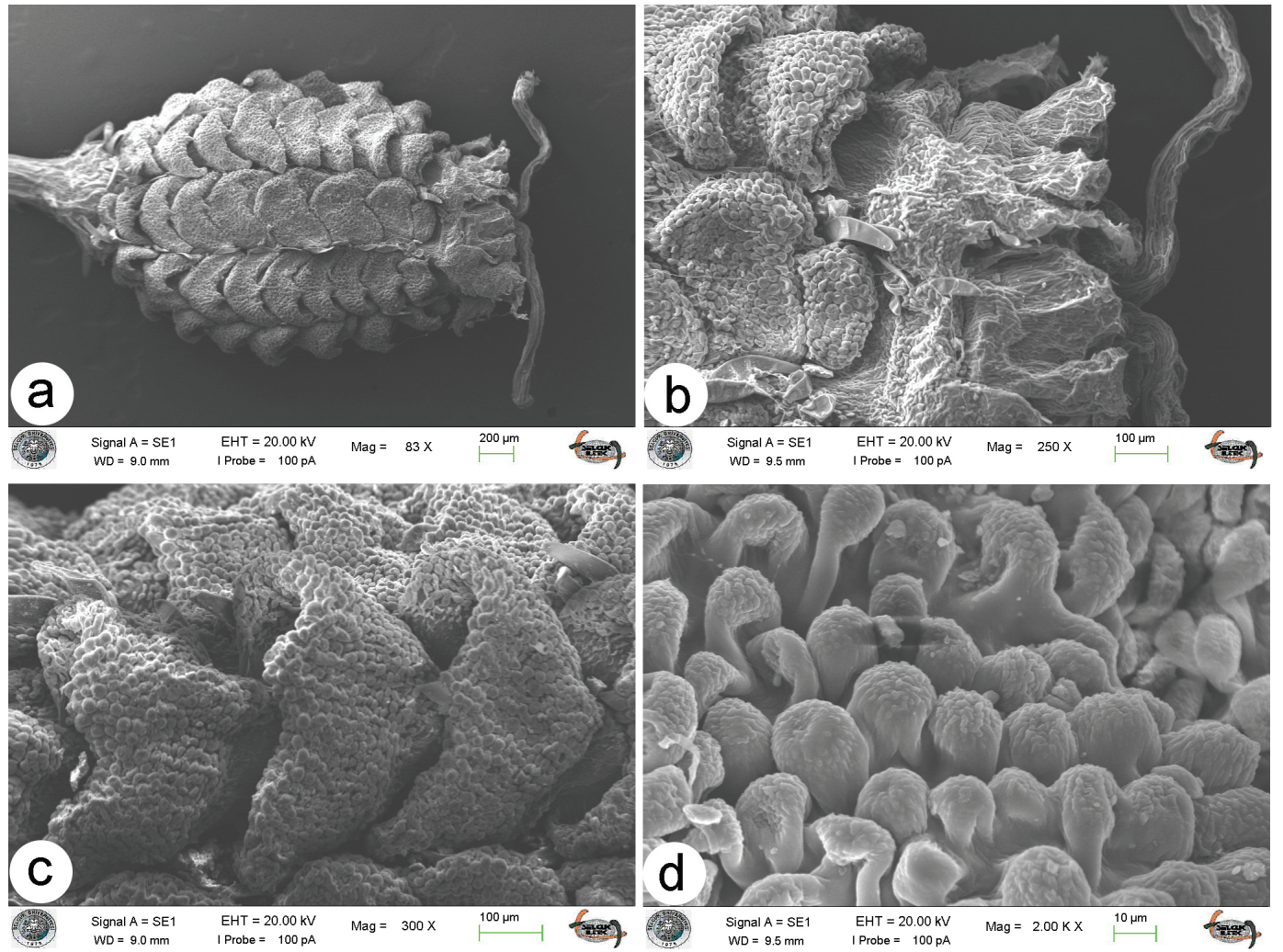

Fig. 5. SEM images of fruits of Szovitsia callicarpa: a, general shape of fruit; $\mathbf{b}$, close view of the calyx teeth, stylopodium and base of the style; $\mathbf{c}$, close view of the plicae; $\mathbf{d}$, view of papillae on the surface of a plica. 


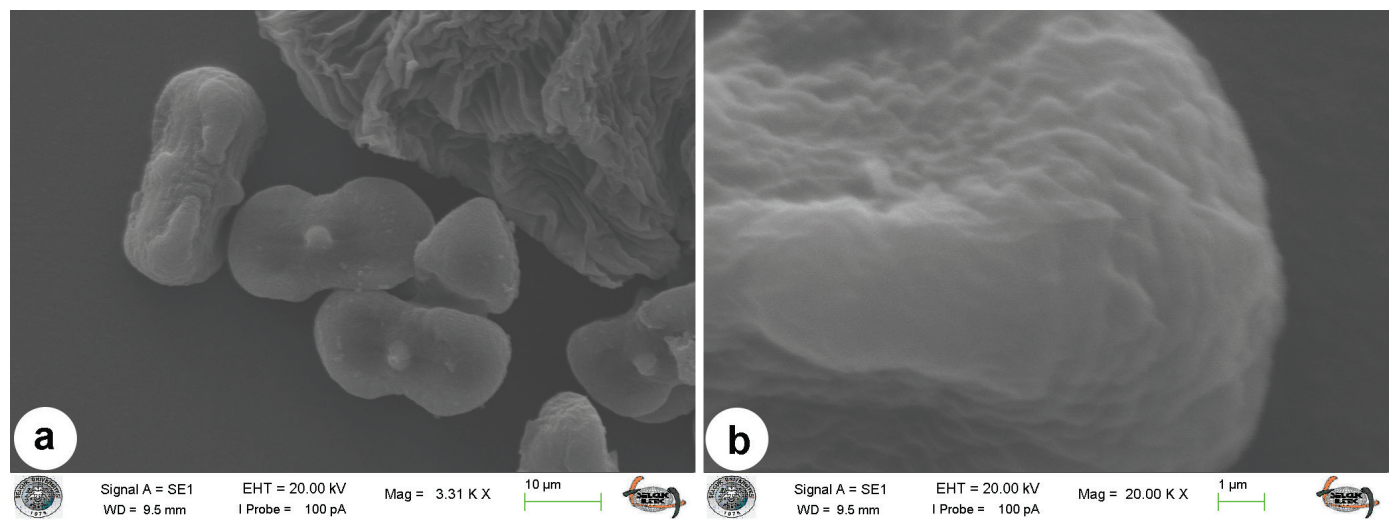

Fig. 6. SEM images of pollen grains of Szovitsia callicarpa: $\mathbf{a}$, general view; $\mathbf{b}$, detail of pollen grain surface.
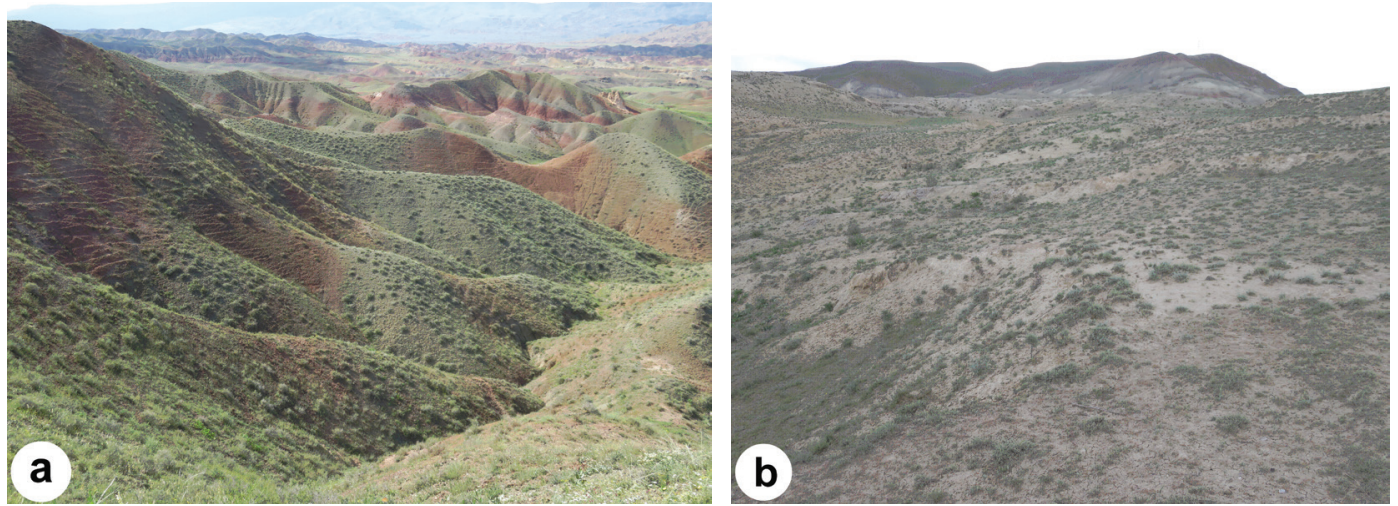

Fig. 7. Habitats of Szovitsia callicarpa in Turkey: a, View of site between Tuzluca and Kağızman; b, Site located northeast of Tuzluca.

occurring with S. callicarpa are: Allochrusa versicolor (Fisch. \& C.A.Mey.) Boiss., Arnebia pulchra (Willd. ex Roem. \& Schult.) J.R.Edm., Artemisia santonicum L., Asphodeline prolifera (M.Bieb.) Kunth, Astragalus dictyophysus Reut. ex Bunge, Astragalus latifolius Lam., Atraphaxis spinosa, Brachypodium distachyon (L.) P.Beauv., Bunium microcarpum (Boiss.) Freyn \& Bornm., Matthiola odoratissima (M.Bieb.) R.Br., Phlomoides laciniata (L.) Kamelin \& Makhm., Polygala supina Schreb. subsp. rhodopea (Velen.) McNeill, Stachys araxina Kopell., and Stipa pulcherrima K.Koch.

The most traditional classifications of Apiaceae have relied almost exclusively on fruit characters (Plunkett \& Downie 1999). The genus Szovitsia is unusual within the family Apiaceae by its fruit with secondary ribs that are covered by plicae. Ledebour (1844) has considered Szovitsia to be closely related to Caucalis L., Turgenia Hoffm., and Torilis Adans. and placed it in the Caucalineae tribe. Later on, Szovitsia was placed in the Caucalineae tribe in Haplozygiae along Ormosciadium Boiss., Coriandrum L., Bifora Hoffm., Cuminum L., Trepocarpus Nutt ex. DC., Ammiopsis Boiss., Exoacantha Labill., Artedia L., Daucus L., Caucalis, and Psammogeton Edgew. in the classification of Bentham (1867).

A comprehensive molecular phylogenetic analysis of Caucalideae, Scandiceae, and related taxa, based on DNA sequences, showed that Glochidotheca Fenzl. is sister to the Turgenia, Lisaea Boiss., Caucalis clades and that Szovitsia allies with Astrodaucus Drude (Lee \& Downie 1999; Lee \& Downie 2000). Lee \& Downie (2000) indicated that the group can be characterized by two synapomorphies - the presence of curved primary hairs and the presence of peg-like projections on the surface of secondary appendages. Further studies on species relationships within the spiny-fruited umbellifers (Scandiceae subtribes Daucinae and Torilidinae) (Lee \& al. 2001) show that subtribe Torilidinae includes three major lineages-Astrodaucus, Torilis, and Caucalis. 
The Austrodaucus subclade comprises Astrodaucus, Glochidotheca, and Szovitsia and share the two synapomorphies mentioned above, although these taxa are remarkably different morphologically (Lee \& al. 2001). Astrodaucus has double rows of pyramid-shaped spines on its secondary ridges, which nearly completely conceal the thread-like primary ridges, whereas Szovitsia is characterized by unique spatulate pouches for the secondary appendages, and Glochidotheca has strongly laterally compressed fruits (Lee \& Downie 1999; Lee \& Downie 2000; Lee \& al. 2001).

\section{ACKNOWLEDGEMENTS}

We thank Ivan Tatanov and the officials at the Leningrad Herbarium for sharing pictures of herbarium samples with us and the Ministry of Agriculture and Forestry, Republic of Turkey, for financial support.

\section{REFERENCES}

Bentham G. 1867. Umbelliferae. In Bentham G. \& Hooker J.D. (eds.), Genera plantarum 1: 859-931. Reeve, London.

Candolle A.P. 1830. Umbelliferae. In Candolle A.P (ed.), Prodromus systematis naturalis regni Vegetabilis vol. 4: 55-250. Treüttel \& Würtz, Paris.

Davis P.H. (ed.). 1965. Introduction. Flora of Turkey and the East Aegean Islands 1: 1-26. Edinburgh University Press, Edinburgh.

Davis P.H. (ed.). 1972. Umbelliferae. Flora of Turkey and the East Aegean Islands 4: 265-538. Edinburgh University Press, Edinburgh.

Ekim T. 2009. Türkiye'nin Nadir Endemikleri (The rare endemics of Turkey). İş Bankası Kültür Yayınları, İstanbul.

Erdtman G. 1952. Pollen morphology and Plant taxonomy I. Angiosperms. Almqvist \& Wikshell, Stockholm.

Faegri K. \& Iversen J. 1975. Textbook of pollen analysis. $3^{\text {rd }}$ ed. New York, Hafner.

Fischer F.E.L. \& Meyer C.A. 1835. Index Seminum, quae Hortus Botanicus Imperialis Petropolitanus pro Mutua Commutatione Offert. Accedunt Animadversiones Botanicae Nonnullae 1: 1-42. St. Petersburg.

Güner A., Aslan S., Ekim T., Vural, M \& Babaç M.T. (eds.) 2012. Türkiye Bitkileri Listesi (Damarlı Bitkiler). Neazahat Gökyiğit Botanik Bahçesi ve Flora Araştırma Derneği Yayını, İstanbul.
Koch W.D.J. 1824. Generum tribuumque plantarum Umbelliferarum nova dispositio. Nova Acta Academiae Caesareae Leopoldino-Carolinae Germanicae Naturae Curiosorum 12: 55-156.

Ledebour K.F.V. 1844. Flora Rossica; sive, Enumeratio plantarum in totius Imperii Rossici provinciis Europaeis, Asiaticis et Americanis hucusque observatarum vol 2., Sumptibus Librariae E. Schweizerbart, Stuttgart.

Lee B.Y. \& Downie S.R 1999. A Molecular Phylogeny of Apiaceae tribe Caucalideae and related taxa: inferences based on ITS sequence data. Systematic Botany 24: 461-479.

Lee B.Y. \& Downie S.R 2000. Phylogenetic analysis of cpDNA restriction sites and rps 16 intron sequences reveals relationships among Apiaceae tribes Caucalideae, Scandiceae and related taxa. Plant Systematics and Evolution 221: 35-60.

Lee B.Y., Levin G.A. \& Downie S.R. 2001. Relationships within the spinyfruited Umbellifers (Scandiceae subtribes Daucinae and Torilidinae) as assessed by phylogenetic analysis of morphological character. Systematic Botany 26: 622-642.

Peşmen H. 1972. Szovitsia Fisch. \& C.A.Mey. In Davis P.H. (ed.), Flora of Turkey and the East Aegean Island 4: 419-420. Edinburgh University Press, Edinburgh.

Pimenov M.G. \& Leonov M.V. 2004a. Asia, the continent with the highest Umbelliferae biodiversity. South African Journal of Botany 70: 417-419.

Pimenov M.G. \& Leonov M.V. 2004b. The Asian Umbelliferae Biodiversity Database (ASIUM) with particular reference to South-West Asian taxa. Turkish Journal of Botany 28: 139-145.

Plunkett G.M. \& Downie S.R. 1999. Major lineages within Apiaceae subfamily Apioideae: a comparison of chloroplast restriction site and DNA sequence data. American Journal of Botany 86: 1014-1026.

Rechinger K.H. 1987. Szovitsia. In Rechinger K.H. \& Hedge I.C. (eds.) Flora Iranica 162: 157-158. Akademische Druck and Verlagsanstalt, Graz, Austria.

Rechinger K.H. \& Hedge I.C. (eds.) 1987. Flora Iranica 162. Akademische Druck und Verlagsanstalt, Graz.

Sales F. \& Hedge I.C. 2013. Generic endemism in South-West Asia: an overview. Rostaniha 14: 22-35.

Shner J.V., Pimenov M.G. \& Hljuykov E.U. 2005. Reports 1438-142. In Kamari G., Blanché C., Garbari F. (eds), Mediterrenean chromosome number reports-15. Flora Mediterranea 15: 693-728.

Shishkin B.K. 1973. Szovitsia Fisch. \& C.A.Mey. In Shishkin B.K. (ed.), Flora of USSR 16: 261-262. Akademi Nauk SSSR, Moskow \& Leningrad.

Wodehouse R.P. 1935. Pollen Grains. Their Structure, Identification and Significance in Science and Medicine. McGraw-Hill Book Company. NewYork and London. 